Acta Crystallographica Section E

Structure Reports

Online

ISSN 1600-5368

Filipe A. Almeida Paz, ${ }^{a}$ Marcia C. Neves, ${ }^{b}$ Tito Trindade ${ }^{b}$ and Jacek Klinowski $^{\text {a* }}$

${ }^{a}$ Department of Chemistry, University of Cambridge, Lensfield Road, Cambridge CB2 1EW, England, and ${ }^{\mathbf{b}}$ Department of Chemistry, University of Aveiro, CICECO, 3810-193 Aveiro, Portugal

Correspondence e-mail: jk18@cam.ac.uk

Key indicators

Single-crystal X-ray study

$T=180 \mathrm{~K}$

Mean $\sigma(\mathrm{C}-\mathrm{C})=0.009 \AA$

Disorder in main residue

$R$ factor $=0.066$

$w R$ factor $=0.196$

Data-to-parameter ratio $=27.2$

For details of how these key indicators were automatically derived from the article, see http://journals.iucr.org/e.
(C) 2003 International Union of Crystallography Printed in Great Britain - all rights reserved

\title{
The first dinuclear zinc(II) dithiocarbamate complex with butyl substituent groups
}

The crystal structure of the title compound, $\operatorname{bis}(\mu-N, N-$ dibutyldithiocarbamato- $\left.\kappa^{2} S: S^{\prime}\right)$ bis $[(N, N$-dibutyldithiocarbal-forcelb]mato- $\left.\left.\kappa^{2} S, S^{\prime}\right) \operatorname{zinc}(\mathrm{II})\right], \quad\left[\mathrm{Zn}_{2}\left(\mathrm{C}_{9} \mathrm{H}_{18} \mathrm{NS}_{2}\right)_{4}\right]$, has been determined at $180 \mathrm{~K}$. The structure contains two crystallographically unique $\mathrm{Zn}^{2+}$ metal centres, showing almost identical slightly distorted tetrahedral coordination environments, and forming a dinuclear complex with two skew-bridging syn- $N, N$-dibutyldithiocarbamate ligands. Two other dithiocarbamate ligands are connected to the $\mathrm{Zn}^{2+}$ centres in a syn,syn-chelate coordination mode.

\section{Comment}

Metal dithiocarbamate complexes have been known for a long time, with the first crystallographic result dating back 50 years, when Simonsen \& Ho (1953) reported the space group and unit-cell parameters for the structure of the ethyl analogue of the title compound. There has been a recent renewal of interest in this type of compound, which can act as a molecular precursor in the synthesis of novel metal sulfide nanomaterials (Trindade et al., 2001). Such compounds have been successfully used as single-molecule precursors to prepare a wide range of nanocrystalline semiconductors, such as $\mathrm{ZnS}$ (Malik et al., 2001), CdS (Monteiro et al., 2002; Lazzel \& O'Brien, 1999; Trindade, O'Brien \& Zhang, 1997), PbS (Trindade, O'Brien, Zhang \& Motevalli, 1997) and $\mathrm{Bi}_{2} \mathrm{~S}_{3}$ (Monteiro et al., 2001). ZnS, a technologically important material as a phosphor and as a white pigment, can be prepared from a well known

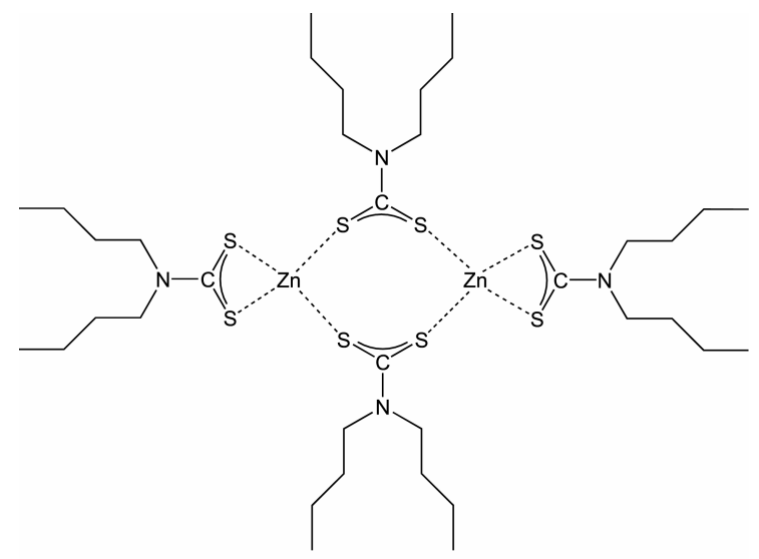

(I)

zinc(II) diethyldithiocarbamate complex $\left[\mathrm{Zn}_{2}\left(\mathrm{C}_{5} \mathrm{H}_{10} \mathrm{NS}_{2}\right)_{4}\right]$, the crystal structure of which has been extensively studied (Simonsen \& Ho, 1953; Bonamico et al., 1965; Zvonkova et al., 1967; Tiekink, 2000). A search in the Cambridge Structural Database (Allen, 2002) reveals that an analogous compound containing methyl substituents, viz. $\left[\mathrm{Zn}_{2}\left(\mathrm{C}_{3} \mathrm{H}_{6} \mathrm{NS}_{2}\right)_{4}\right]$, has
Received 20 October 2003 Accepted 21 October 2003 Online 31 October 2003 


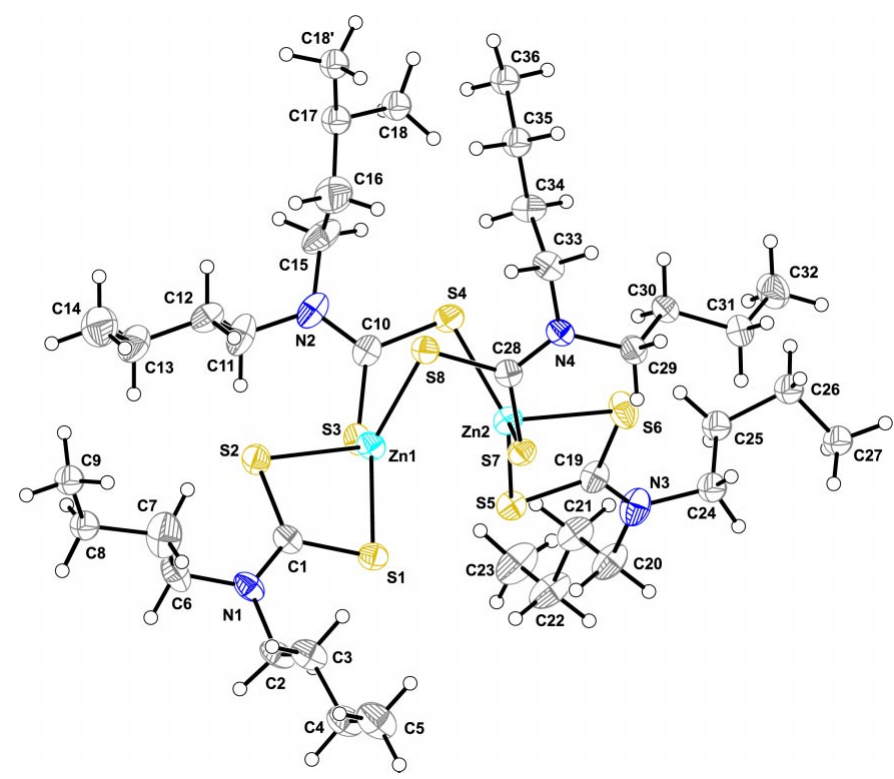

Figure 1

The molecular structure of (I), with displacement ellipsoids drawn at the $30 \%$ probability level, $\mathrm{H}$ atoms as small spheres, and the labelling scheme for all non-H atoms. Disordered $\mathrm{H}$ atoms on $\mathrm{C} 17$ have been omitted for clarity; atom $\mathrm{C} 18$ is disordered over two different positions.
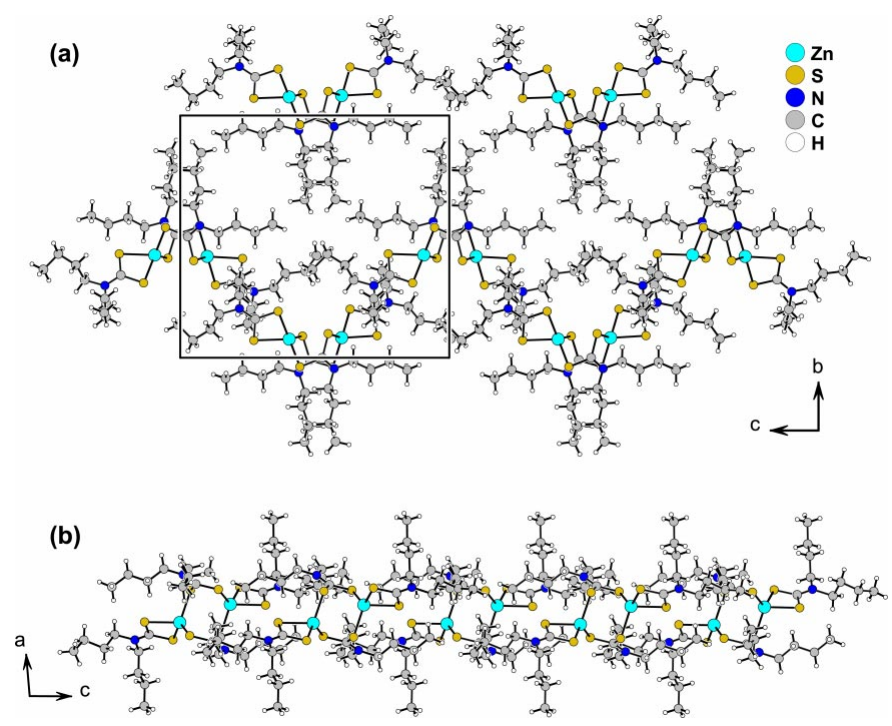

Figure 2

Perspective views, along the $a$ (top) and $b$ (bottom) axes, of the layers in the $b c$ plane, formed by the parallel stacking of $\left[\mathrm{Zn}_{2}\left(\mathrm{C}_{9} \mathrm{H}_{18} \mathrm{NS}_{2}\right)_{4}\right]$ molecules related by the $2_{1}$ screw axis.

been described (Klug, 1966; Ramalingam et al., 1998). We report here the first crystal structure of a dinuclear zinc(II) dithiocarbamate complex with butyl substituent groups, $\left[\mathrm{Zn}_{2}\left(\mathrm{C}_{9} \mathrm{H}_{18} \mathrm{NS}_{2}\right)_{4}\right]$, (I).

Compound (I) crystallizes in the monoclinic space group $P 2_{1} / c$, with one complete dinuclear $\left[\mathrm{Zn}_{2}\left(\mathrm{C}_{9} \mathrm{H}_{18} \mathrm{NS}_{2}\right)_{4}\right]$ complex molecule in the asymmetric unit (Fig. 1). The crystallographically unique $\mathrm{Zn}^{2+}$ metal centres have approximately identical distorted tetrahedral coordination environments

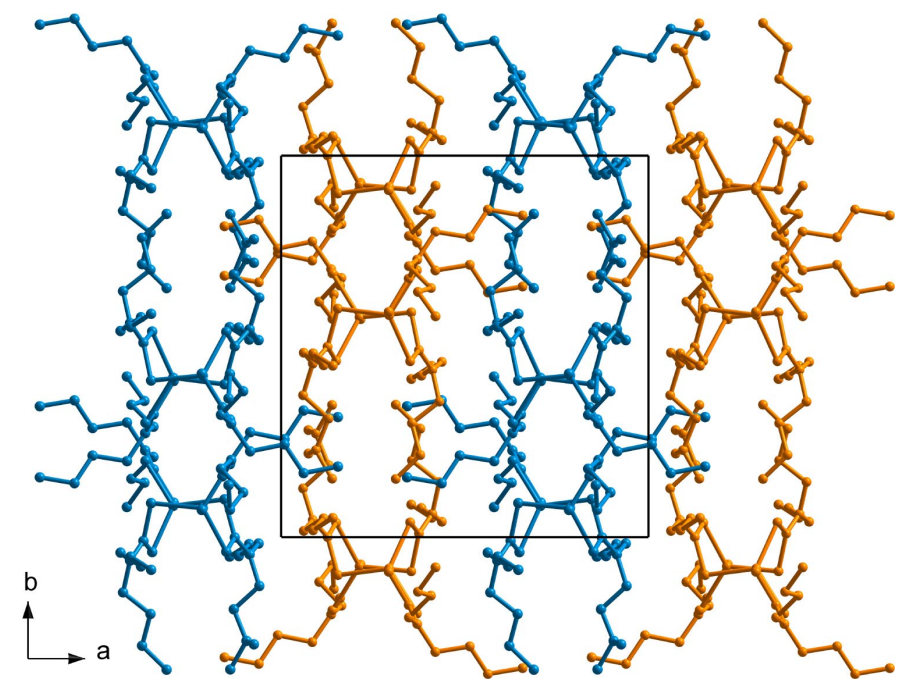

Figure 3

Schematic representation of the alternation in an $A B A B \ldots$ fashion along the $a$ axis (due to the $c$-glide plane), of layers (in blue and orange) of $\left[\mathrm{Zn}_{2}\left(\mathrm{C}_{9} \mathrm{H}_{18} \mathrm{NS}_{2}\right)_{4}\right]$ molecules. $\mathrm{H}$ atoms have been omitted for clarity.

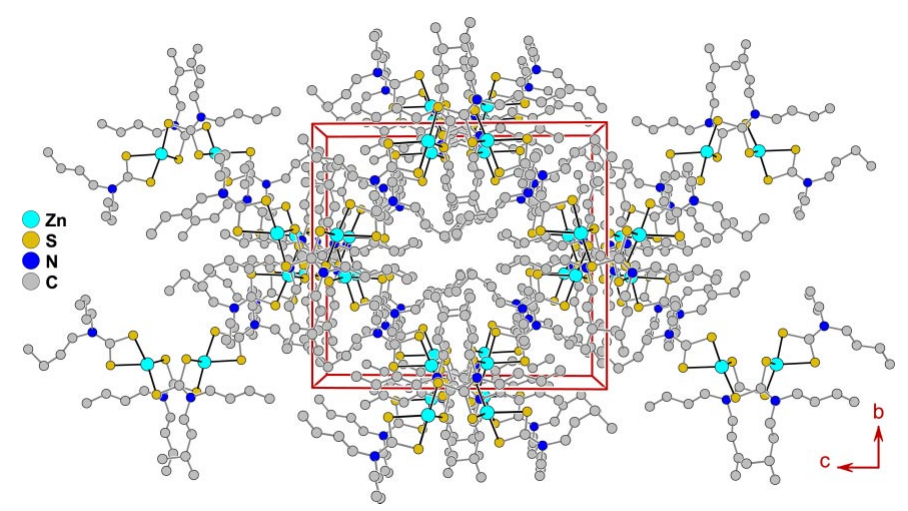

Figure 4

Perspective view of (I) along the $a$ axis. $\mathrm{H}$ atoms have been omitted for clarity.

(Table 1), and are bridged by two $N, N$-dibutyldithiocarbamate ligands in a skew syn coordination fashion, imposing a $\mathrm{Zn} 1 \cdots \mathrm{Zn} 2$ separation of 3.7141 (12) ̊ (Fig. 1). Each metal centre is further connected to another organic ligand in a syn,syn-chelating coordination fashion. Molecules related by the $2_{1}$ screw axis close-pack in the $b c$ plane to form layers (Fig. 2), which alternate in an $A B A B \ldots$ fashion along the $a$-axis direction (Fig. 3), leading to the complete crystal structure of (I) (Fig. 4).

\section{Experimental}

All chemicals were purchased from Aldrich and used without further purification. $\mathrm{CS}_{2}(4.13 \mathrm{mmol})$ was added to an ethanol suspension ( $\mathrm{ca}$ $50 \mathrm{ml})$ containing dibutylamine $\left(\mathrm{C}_{8} \mathrm{H}_{19} \mathrm{~N}, 4.13 \mathrm{mmol}\right)$ and freshly prepared zinc(II) hydroxide $\left[\mathrm{Zn}(\mathrm{OH})_{2}, 2.07 \mathrm{mmol}\right]$, and the resulting mixture was stirred overnight at ambient temperature. A white precipitate was isolated by vacuum filtration and was air-dried at 333 K. Moderate-quality colourless crystals of the title compound suitable for $\mathrm{X}$-ray diffraction were obtained by recrystallization from $\mathrm{CH}_{2} \mathrm{Cl}_{2}$ over a period of $2 \mathrm{~d}$. 
Crystal data

$$
\begin{aligned}
& {\left[\mathrm{Zn}_{2}\left(\mathrm{C}_{9} \mathrm{H}_{18} \mathrm{NS}_{2}\right)_{4}\right]} \\
& M_{r}=948.20 \\
& \text { Monoclinic, } P 2_{1} / c \\
& a=16.036(3) \AA \\
& b=16.604(3) \AA \\
& c=18.487(4) \AA \\
& \beta=95.10(3)^{\circ} \\
& V=4902.7(17) \AA^{3} \\
& Z=4
\end{aligned}
$$

$D_{x}=1.285 \mathrm{Mg} \mathrm{m}^{-3}$

Mo $K \alpha$ radiation

Cell parameters from 22557

reflections

$\theta=1.0-27.5^{\circ}$

$\mu=1.35 \mathrm{~mm}^{-1}$

$T=180(2) \mathrm{K}$

Block, colourless

$0.14 \times 0.12 \times 0.10 \mathrm{~mm}$

\section{Data collection}

Nonius KappaCCD diffractometer

Thin-slice $\omega$ and $\varphi$ scans

Absorption correction: multi-scan (SORTAV; Blessing, 1995)

$T_{\min }=0.748, T_{\max }=0.877$

30156 measured reflections

11123 independent reflections

\section{Refinement}

Refinement on $F^{2}$

$R\left[F^{2}>2 \sigma\left(F^{2}\right)\right]=0.066$

$w R\left(F^{2}\right)=0.196$

$S=1.04$

11123 reflections

409 parameters

$\mathrm{H}$-atom parameters constrained

Table 1

Selected geometric parameters $\left(\AA{ }^{\circ}\right)$.

\begin{tabular}{lrlr}
\hline Zn1-S8 & $2.3164(14)$ & $\mathrm{N} 1-\mathrm{C} 1$ & $1.329(5)$ \\
$\mathrm{Zn} 1-\mathrm{S} 1$ & $2.3468(13)$ & $\mathrm{S} 3-\mathrm{C} 10$ & $1.755(5)$ \\
$\mathrm{Zn} 1-\mathrm{S} 3$ & $2.3659(13)$ & $\mathrm{S} 4-\mathrm{C} 10$ & $1.722(5)$ \\
$\mathrm{Zn} 1-\mathrm{S} 2$ & $2.4365(14)$ & $\mathrm{N} 2-\mathrm{C} 10$ & $1.316(6)$ \\
$\mathrm{Zn} 2-\mathrm{S} 4$ & $2.3118(14)$ & $\mathrm{S} 5-\mathrm{C} 19$ & $1.723(5)$ \\
$\mathrm{Zn} 2-\mathrm{S} 5$ & $2.3406(13)$ & $\mathrm{S} 6-\mathrm{C} 19$ & $1.723(5)$ \\
$\mathrm{Zn} 2-\mathrm{S} 7$ & $2.3660(13)$ & $\mathrm{N} 3-\mathrm{C} 19$ & $1.332(6)$ \\
$\mathrm{Zn} 2-\mathrm{S} 6$ & $2.4390(16)$ & $\mathrm{S} 7-\mathrm{C} 28$ & $1.747(5)$ \\
$\mathrm{S} 1-\mathrm{C} 1$ & $1.734(5)$ & $\mathrm{S} 8-\mathrm{C} 28$ & $1.722(4)$ \\
$\mathrm{S} 2-\mathrm{C} 1$ & $1.719(5)$ & $\mathrm{N} 4-\mathrm{C} 28$ & $1.320(5)$ \\
& & & \\
$\mathrm{S} 8-\mathrm{Zn} 1-\mathrm{S} 1$ & $125.51(5)$ & $\mathrm{S} 5-\mathrm{Zn} 2-\mathrm{S} 7$ & $119.42(5)$ \\
$\mathrm{S} 8-\mathrm{Zn} 1-\mathrm{S} 3$ & $112.59(5)$ & $\mathrm{S} 4-\mathrm{Zn} 2-\mathrm{S} 6$ & $109.85(6)$ \\
$\mathrm{S} 1-\mathrm{Zn} 1-\mathrm{S} 3$ & $116.50(5)$ & $\mathrm{S} 5-\mathrm{Zn} 2-\mathrm{S} 6$ & $106.59(5)$ \\
S8-Zn1-S2 & $110.67(5)$ & $\mathrm{S} 7-\mathrm{Zn} 2-\mathrm{S} 6$ & $117.2(3)$ \\
$\mathrm{S} 1-\mathrm{Zn} 1-\mathrm{S} 2$ & $76.05(5)$ & $\mathrm{S} 2-\mathrm{C} 1-\mathrm{S} 1$ & $118.4(3)$ \\
$\mathrm{S} 3-\mathrm{Zn} 1-\mathrm{S} 2$ & $107.05(5)$ & $\mathrm{S} 4-\mathrm{C} 10-\mathrm{S} 3$ & $117.3(3)$ \\
$\mathrm{S} 4-\mathrm{Zn} 2-\mathrm{S} 5$ & $123.14(5)$ & $\mathrm{S} 6-\mathrm{C} 19-\mathrm{S} 5$ & $118.6(3)$ \\
S4-Zn2-S7 & $112.71(5)$ & $\mathrm{S} 8-\mathrm{C} 28-\mathrm{S} 7$ & \\
\hline
\end{tabular}

All $\mathrm{H}$ atoms were positioned geometrically and refined in the riding-model approximation, with $U_{\text {iso }}(\mathrm{H})$ values fixed at 1.2 (methylene $\mathrm{H}$ atoms) or 1.5 (methyl $\mathrm{H}$ atoms) times $U_{\text {eq }}$ of the parent atom. The alkyl chains were found to be severely affected by disorder, with some $\mathrm{C}$ atoms showing extended ellipsoids when treated with anisotropic displacement parameters. Attempts to model disorder for these alkyl chains resulted in a negligible improvement; the crystal used for data collection, the best from several batches, was a very small block of only moderate quality. However, refinement of the crystal structure with strong geometrical restraints for the alkyl chains (approximately equal $\mathrm{C}-\mathrm{C}$ bond lengths and $\mathrm{C}-\mathrm{C}-\mathrm{C}$ angles), and common isotropic displacement parameters for some $\mathrm{C}$ atoms, resulted in a satisfactory solution. Disorder for atom C18 was successfully modelled over two different positions (C18 and $\left.\mathrm{C} 18^{\prime}\right)$ with occupancy factors of 0.600 (13) and 0.400 (13), respectively. The highest peak in the final difference map is located $0.09 \AA$ from C36, and the deepest hole is $0.75 \AA$ from S6.

Data collection: COLLECT (Nonius, 1998); cell refinement: $H K L$ SCALEPACK (Otwinowski \& Minor, 1997); data reduction: $H K L$ DENZO (Otwinowski \& Minor, 1997) and SCALEPACK; program(s) used to solve structure: SIR92 (Altomare et al., 1994); program(s) used to refine structure: SHELXTL (Bruker, 2001); molecular graphics: $S H E L X T L$; software used to prepare material for publication: $S H E L X T L$.

We are grateful to the University of Aveiro (project No. 3.64.33.7/NANOENG/CTS15) and the Portuguese Foundation for Science and Technology (FCT) for financial support through PhD scholarship No. SFRH/BD/3024/2000 to FAAP.

\section{References}

Allen, F. H. (2002). Acta Cryst. B58, 380-388.

Altomare, A., Cascarano, G., Giacovazzo, C., Guagliardi, A., Burla, M. C., Polidori, G. \& Camalli, M. (1994). J. Appl. Cryst. 27, 435.

Blessing, R. H. (1995). Acta Cryst. A51, 33-58.

Bonamico, M., Mazzone, G., Vaciago, A. \& Zambonelli, L. (1965). Acta Cryst. 19, 898-909.

Bruker (2001). SHELXTL. Version 6.12. Bruker AXS Inc., Madison, Wisconsin, USA.

Klug, H. P. (1966). Acta Cryst. 21, 536-546.

Lazzel, M. \& O'Brien, P. (1999). Chem. Commun. pp. 2041-2042.

Malik, M. A., O'Brien, P. \& Revaprasadu, N. (2001). J. Mater. Chem. 11, 2382 2386.

Monteiro, O. C., Esteves, A. C. C. \& Trindade, T. (2002). Chem. Mater. 14, 2900-2904.

Monteiro, O. C., Nogueira, H. I. S., Trindade, T. \& Motevalli, M. (2001). Chem. Mater. 13, 2103-2111.

Nonius (1998). COLLECT. Nonius BV, Delft, The Netherlands.

Otwinowski, Z. \& Minor, W. (1997). Methods in Enzymology, Vol. 276, Macromolecular Crystallography, Part A, edited by C. W. Carter Jr and R. M. Sweet, pp. 307-326. New York: Academic Press.

Ramalingam, K., bin Shawkataly, O., Fun, H.-K. \& Razak, I. A. (1998). Z. Kristallogr. New Cryst. Struct. 213, 371-372.

Simonsen, S. H. \& Ho, J. W. (1953). Acta Cryst. 6, 430.

Tiekink, E. R. T. (2000). Z. Kristallogr. New Cryst. Struct. 215, 445-446.

Trindade, T., O’Brien, P. \& Pickett, N. (2001). Chem. Mater. 13, 3843-3858.

Trindade, T., O'Brien, P. \& Zhang, X. (1997). Chem. Mater. 9, 523-530.

Trindade, T., O’Brien, P., Zhang, X. \& Motevalli, M. (1997). J. Mater. Chem. 7, 1011-1016.

Zvonkova, Z. V., Khvatkina, A. N. \& Isanova, N. S. (1967). Kristallografiya (Russ.) (Crystallogr. Rep.), 12, 1065. 